\title{
Selaginella devolii (Selaginellaceae), a new species from Taiwan
}

\author{
H.-M. Chang ${ }^{1}$, P.-F. Lu², T.-C. Hsu³, W.-L. Chiou ${ }^{3}$
}

\section{Key words}

IUCN Red List

Selaginella devolii

Selaginellaceae

Taiwan

taxonomy

\begin{abstract}
Selaginella devolii sp. nov. is described from four populations located in central and southern Taiwan. It is an annual prostrate lycophyte, growing on moist rocky slopes. Its diagnostic characteristics include its small size, tiny broadly ovate trophophylls, complanate strobili, and sporangia which are only formed at the ventral sporophylls. Notes on taxonomy and distribution and a line illustration are provided.
\end{abstract}

Published on 2 March 2011

\section{INTRODUCTION}

Selaginellaceae is a monotypic family, with about 750 species worldwide (Jermy 1990). In Taiwan, 15 species of Selaginella have been recorded (DeVol 1979, Tsai \& Shieh 1994, Chang et al. 2009). Here we report a new moss- or Azolla-like species, S. devolii, in central and southern Taiwan. This new spike-moss appears to be the smallest in the Taiwan and neighbouring region. It was probably overlooked because of its minuteness, and the first collection was only made in 2001. Another three populations were later found, also in central-southern Taiwan. In this paper, $S$. devolii is described and its taxonomy discussed.

\section{Selaginella devolii H.M.Chang, P.F.Lu \& W.L.Chiou, sp. nov.} — Fig. 1; Map 1

Species S. kouytcheensis similis, sed foliis minoris differt. Planta $1-3 \mathrm{~cm}$ longa; omnino glabra, caulis procumbens ramosis, trophophyllis ventralibus ovatis vel late oblongus, $1-1.3 \mathrm{~mm}$ longis, 0.7-0.9 mm latis. - Typus: HoMing Chang 6635 (holo TAIF; iso L, TAIE), Taiwan, Nantou County, Chushan, Fuchouli Village, Fangliao, 23 Oct. 2009.

Etymology. This new species is dedicated to Charles E. DeVol (19031989), a kind taxonomist who studied Taiwanese Selaginellaceae (DeVol \& Chen 1966) and was an editor for the Flora of Taiwan, 1st ed.

Annual prostrate lycophyte, very small, without erect or ascending stems. Stems widely branching with main segments 1-3 $\mathrm{cm}$ long, 2-2.5 $\mathrm{mm}$ wide (rarely broader than $3 \mathrm{~mm}$ ) across microphylls, decumbent or creeping. Rhizophores present along basal branches. Trophophylls conspicuously dimorphic, arranged in 4 ranks (2 dorsal and 2 ventral), vein single, prominent on the ventral side, usually not reaching the apex, margin with 1-2 rows of specialized, elongated cells; axillary trophophylls present at branch forks, inserted at the ventral side of the stem, broadly ovate to elliptic, sparsely serrulate along margin; ventral (lateral) trophophylls broadly ovate or broadly oblong, rarely ovate, $1-1.3 \mathrm{~mm}$ long, $0.7-0.9 \mathrm{~mm}$ wide, rounded or somewhat cordate at base, rounded or broadly acute at apex, usually sparsely serrulate along margin but sometime

\footnotetext{
Endemic Species Research Institute, 1 Ming-Sheng E. Rd., Jiji, Nantou 55244, Taiwan.

2 Taiwan Society of Plant Systematics, 88 Ting-Chow Rd., Sec 4, Taipei 11677, Taiwan.

3 Taiwan Forestry Research Institute, 53 Nanhai Rd., Taipei 10066, Taiwan; corresponding author e-mail: chiou@tfri.gov.tw.
}

entire at the basiscopic $2 / 3$; dorsal (median) trophophylls ovate or broadly elliptic, $0.5-0.8 \mathrm{~mm}$ long, $0.3-0.6 \mathrm{~mm}$ wide, base rounded or truncate, apex acute to rounded, margin sparsely serrulate. Strobili terminal to branches, complanate, 3-10 $\mathrm{mm}$ long, 2.5-3 $\mathrm{mm}$ wide; sporangia on the ventral side only, megasporangia at the basal parts and microsporangia more apically; dorsal sporophylls significantly larger than ventral ones; dorsal sporophylls widely spreading, broadly falcate, 1-1.3 $\mathrm{mm}$ long, $0.5-0.7 \mathrm{~mm}$ wide, sparsely serrulate along margin, acute to rounded at apex, the single vein bearing a keel-like wing along its basal half on the ventrally facing adaxial side, margin of the wing toothed; ventral sporophylls pointing forward, shovel-like, ovate or broadly lanceolate, vein prominent on the ventrally facing abaxial side, $0.7-0.9 \mathrm{~mm}$ long, $0.4-0.5 \mathrm{~mm}$ wide, serrulate along the margin apically but toothed nearer the base, acuminate or acute, rounded at the base.

Distribution \& IUCN Red List category - This new species is endemic to Taiwan. Four populations were found in central and southern Taiwan (Map 1). The occupied area in each distribution site was estimated less than $400 \mathrm{~m}^{2}$. Weed control via weeding and/or burning by human was often implemented in the distribution sites. These disturbances have changed illumination conditions and even directly damaged plants of this spike-moss. As there are less than five localities, with an area of occupancy of c. $10 \mathrm{~km}^{2}$, and a decline in quality of habitat owing to human disturbance, the conservation status of this species is considered to be Endangered (EN B2ab(iii)), according to IUCN Red List Categories and Criteria (IUCN 2001).

Habitat \& Ecology - The species grows in the region with seasonal drought. Its habitat is the moist rocky slope with some shade in the wet season. The plants die during the dry season and new plantlets sprout at the beginning of the wet season.

Additional specimens. TAIwAN, Nantou County, Yuchih, Lienhuachih, 640 m, 19 July 2001, T.-W. Hsu 10319 (TAIE); Nantou County, Chushan, Lingchiao to Taan, c. 650 m, 25 Sept. 2006, T.-C. Hsu 613 (TAIF); same location, 8 Nov. 2007, H.-M. Chang 6712 (TAIE, TI, TNU); Kaohsiung County, Meishan Village, 1200 m, 26 Sept. 2004, P.-F. Lu 8713 (TAIF).

Notes - Following Jermy (1990), S. devolii would belong to subg. Heterostachys Baker, in which complanate strobili with dimorphic sporophylls are diagnostic. The new species has sporangia only on the ventral side of strobili, unlike in other Taiwanese species. The dorsal sporophylls provide a laminal flap or pteryx (Quansah \& Thomas 1985) that probably helps protect the sporangia. 


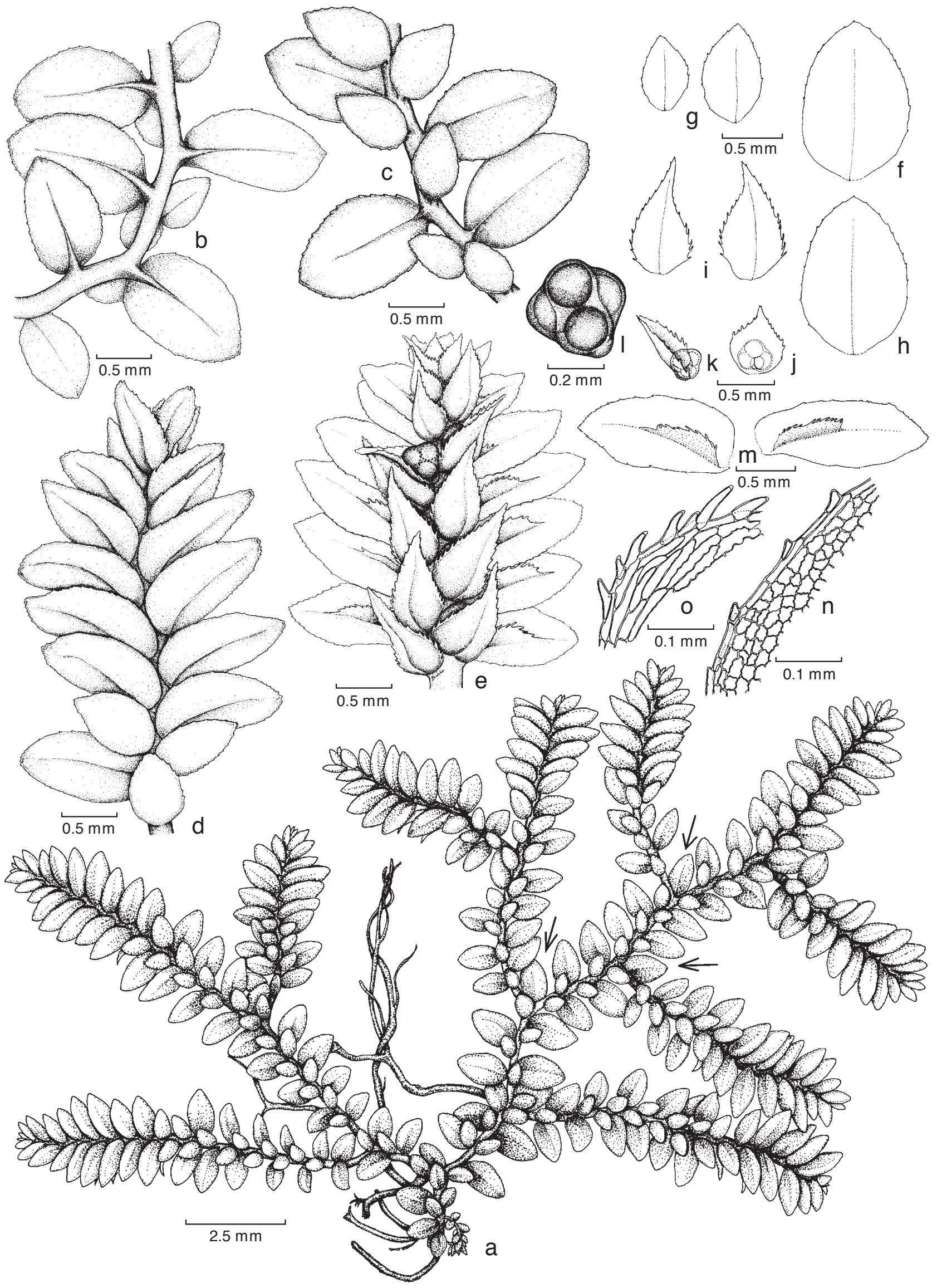

Fig. 1 Selaginella devolii H.M.Chang, P.F.Lu \& W.L.Chiou. a. Mature individual, arrows indicate axillary trophophylls; b. ventral view of sterile branch; c. dorsal view of sterile branch; d. dorsal view of strobilus; e. ventral view of strobilus; f. ventral trophophyll; g. dorsal trophophylls; h. axillary trophophyll; i. ventral sporophylls; j. dorsal view of ventral megasporophyll and megasporangium; k. lateral view of ventral megasporophyll and megasporangium; I. megasporangium; $\mathrm{m}$. ventral view of dorsal sporophylls, showing toothed margin along the keel-like median wing; $\mathrm{n}$. margin of trophophyll; o. margin of basal part of ventral sporophyll (all Chang 6635,TAIF). 

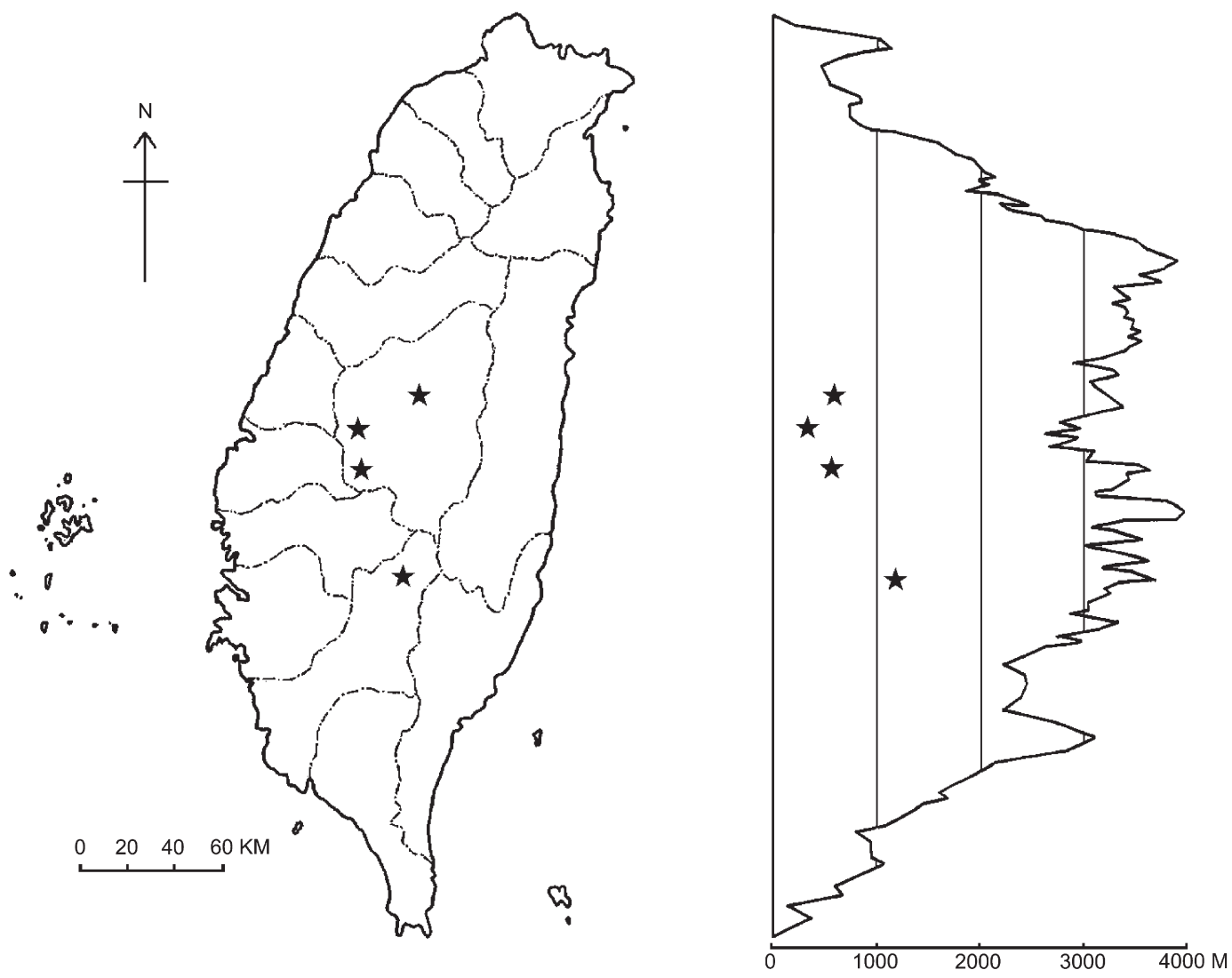

Map 1 Distribution of Selaginella devolii in Taiwan. The profile on the right represents the corresponding elevation above sea level.

Selaginella devolii is similar to S. kouytcheensis H.Lév. of China (Wang 1990, Wang \& Wang 2001) in its minute size, complanate strobili with dorsal sporophylls larger than ventral ones, and serrulate trophophyll margins, but the latter has larger trophophylls $(1.5-2$ by $0.6-1 \mathrm{~mm}$ for ventral; $0.8-1$ by $0.4-0.6 \mathrm{~mm}$ for dorsal), oblong ventral trophophylls, and serrulate ventral sporophophyll margins. In addition, the new species has dorsal sporophylls with a keel-like wing along part of the single vein. In Taiwan, S. devolii most resembles young sporophytes of $S$. leptophylla Baker. However, the latter has oblong ventral trophophylls and lanceolate dorsal ones that easily distinguish it. Selaginella ciliaris (Retz.) Spring, which usually grows together with this new species, has trophophylls and sporophylls with a ciliate margin that makes it different.

Acknowledgements We thank the curators of TAIE and TAIF for permission to examine specimens, Miss Kuei-Chu Chen for preparing the illustration, Miss Ai-Qun Hu and Mr. Yi-Mo Chang for field assistance, and Dr. Tsai-Wen Hsu for kindly communicating population characteristics at Lienhuachih. The authors deeply acknowledge an anonymous reviewer for the valuable comments on this manuscript. This research was partly supported by the Taiwan National Science Council (NSC 98-2321B-054-001).

\section{REFERENCES}

Chang H-M, Chen J-F, Lu P-F, Moore S-J, Wang J-C, Chiou W-L. 2009. Supplements to the lycophytes in Taiwan (I): A newly recorded species Selaginella lutchuensis Koidz. (Selaginellaceae). Taiwania 54: 88-92.

DeVol CE. 1979. A check list of the vascular plants of Taiwan, I. Pteridophyta. In: Li H-L et al. (eds), Flora of Taiwan 6: 5-21. Epoch, Taipei.

DeVol CE, Chen HH-W. 1966. The Pteridophyta of Taiwan 3, Selaginellaceae. Taiwania 12: 56-90.

IUCN. 2001. IUCN Red List Categories and Criteria: Version 3.1. Prepared by the IUCN Species Survival Commission. IUCN, Gland, Switzerland, and Cambridge, UK.

Jermy AC. 1990. Selaginellaceae. In: Kramer KU, Green PS (eds), The families and genera of vascular plants, I. Pteridophytes and Gymnosperms: 39-45. Springer Verlag, Berlin.

Quansah N, Thomas BA. 1985. 'Sporophyll-pteryx' in African and American Selaginella. The Fern Gazette 13, 1: 49-52.

Tsai J-L, Shieh W-C. 1994. Selaginellaceae. In: Huang T-C et al. (eds), Flora of Taiwan, 2nd ed. 1: 29-44. Editorial Committee of the Flora of Taiwan, second edition, Taipei.

Wang P-S. 1990. Notes on the species of Selaginella from Guizhou, China. Journal of Arnold Arboretum 71: 265-270.

Wang P-S, Wang X-Y. 2001. Pteridophyte Flora of Guizhou. Guizhou Science and Technology Publishing House, Guiyang, China. 